\title{
Lead removal kinetics from synthetic effluents using Algerian pine, beech and fir sawdust's: optimization and adsorption mechanism
}

\author{
N. Nordine $\cdot$ Z. El Bahri $\cdot$ H. Sehil • \\ R. I. Fertout $\cdot$ Z. Rais $\cdot$ Z. Bengharez
}

Received: 3 March 2014/ Accepted: 9 September 2014/Published online: 4 October 2014

(c) The Author(s) 2014. This article is published with open access at Springerlink.com

\begin{abstract}
The present paper exposes the lead adsorption from synthetic effluents using natural and available materials. Pine, beech and fir sawdust's were used and compared for their lead adsorption ability. To optimize the sorption phenomenon, some process parameters were studied namely temperature, $\mathrm{pH}$, contact time, initial $\mathrm{Pb}$ (II) concentration, sawdust's dosage and granulometry, stirring speed and medium salinity. The materials were characterized by FTIR spectroscopy, X-ray diffraction and fluorescence. The results demonstrated that the pine sawdust gave the best level for lead adsorption $(15.5 \mathrm{mg} / \mathrm{g})$ in the following conditions and at $23 \pm 2{ }^{\circ} \mathrm{C}$ of temperature : $\mathrm{pH}$ $5.45 \pm 0.05,100 \mathrm{mg} / \mathrm{L}$ of initial $\mathrm{Pb}(\mathrm{II})$ concentration and $10 \mathrm{~g}$ (per liter of solution) of pine sawdust composed from granules with mean diameter lower than $500 \mu \mathrm{m}$. As well, the adsorption kinetics seem to satisfy to Langmuir isotherm model.
\end{abstract}

Keywords $\mathrm{Pb}(\mathrm{II}) \cdot$ Adsorption $\cdot$ Kinetic $\cdot$ Pine sawdust . Isotherm models

N. Nordine $\cdot$ Z. El Bahri $\cdot$ H. Sehil $\cdot$ Z. Bengharez $(\bowtie)$ Laboratoire des Matériaux Avancés et de Physico-chimie pour l'Environnement et Santé, Faculté des Sciences Exactes, Université Djillali Liabes, Sidi Bel Abbes, Algeria e-mail: dzbengharez@yahoo.fr

R. I. Fertout

Laboratoire de Matériaux et Catalyse, Faculté des Sciences Exactes, Université Djillali Liabes, Sidi Bel Abbes, Algeria

\section{Z. Rais}

Laboratoire d'Ingénierie des Matériaux, de Modélisation et d'Environnement, Faculté des Sciences Dhar El Mahraz, Université Sidi Mohamed Ben-Abdellah, Fez, Morocco

\section{Introduction}

Heavy metals are constantly discharged by mining and industrial operations. In contrary of organic pollutants which can degrade, liquid or solid rejections containing metals can cause hazardous environment contamination because the heavy metals are not biodegradable and can lead to accumulation over time along the food chain.

Lead is a heavy metal and known since the Romaine Empire as poison, it can cause serious potential damages in natural reserve of water and marine environment. It has a toxic impact on human body because it can replace calcium and be stored in bones for long periods and affects the bone cells activity via disturbing mineral metabolism (Guimarães et al. 2012; Rosen 1983; Rosin 2009). So its removal from effluents is required for the public health and environment protection.

Hence, numerous methods have been developed to recover or remove this pollutant from effluents; among these elimination processes, we cite electro-coagulation, reverse osmosis, adsorption, precipitation, flotation and electro-dialysis (Mohammadi et al. 2005; Ozaki et al. 2002; Polat and Erdogan 2007; Ramesh et al. 2008; Youcef and Achour 2006; Zongo et al. 2012). Adsorption is one of the interesting methods used for treatment of wastewater charged by this metal. The metal ions can be bind with surface materials by means of physical attractions, complex formation with functional groups or by hydrate formation (Romero-Gonzalez et al. 2001; Crist et al. 1999).

Activated carbon is the most sorbent used on industrial scale for the removal of undesirable and harmful compounds. Since it's more expensive, investigation of some low cost materials has interested the researcher especially native or modified natural materials. For example, Naseem and Tahir (2001) have studied the capacity of bentonite 
clay to remove $\mathrm{Pb}$ (II) from aqueous and acidic solutions. Some experiments were carried out to evaluate the adsorption characteristics of the modified rice bran and straw for $\mathrm{Pb}(\mathrm{II})$ removal from aqueous solutions (Gong et al. 2011; Hengpeng and Zhijuan 2010). Modified and crosslinked chitosan is considered as promising material for lead and in general metal recovery (Xiong et al. 2013; Ren et al. 2013; Parka et al. 2013; Fujiwara et al. 2007). Other materials like modified sugarcane bagasse, modified oak sawdust and degreased coffee beans have been tested for metal removal (Karnitz et al. 2007; Kaikake et al. 2007; Argun et al. 2007).

The present research is interested by lignocellulosic materials obtained from wood processing like sawdust. These residues seem to be a useful alternative for metal biosorption as reported in some papers where different types with different origins of sawdust were tested (Boussahel et al. 2009; Bulut and Tez 2007; Elbariji et al. 2006; Gad et al. 2013; Hidalgo-VÁzquez et al. 2011; Samarghandi et al. 2011; Vaishya and Prasad 1991). In this context, local and available pine, beech and fir sawdust's were tested and compared for their ability to lead biosorption. Kinetics and isotherm of $\mathrm{Pb}$ (II) ion adsorption were established at various experimental conditions to optimize the adsorption rate.

\section{Materials and methods}

\section{Chemicals and materials}

All chemicals were analytical grade. The synthetic wastewater solutions were prepared in double distilled water $(\mathrm{pH}$ 6.5-6.7) using $\mathrm{Pb}\left(\mathrm{NO}_{3}\right)_{2}$ (from Panreac); the dilute solutions at the required concentration for experiments were prepared from initial solution at $1,000 \mathrm{mg} / \mathrm{L}$ of $\mathrm{Pb}(\mathrm{II})$.

To change and adjust the $\mathrm{pH}$, nitric acid solution (0.01 M, from Cheminova) and Sodium hydroxide solution (0.1 M, from Normapur) were used. Sodium chloride (from Merck) was added as electrolyte for the salinity effect study section.

Sawdust preparation and characterization

Sawdust was provided from Algerian joinery manufactures in Sidi Bel Abbes region (Northwest Algeria) and in period of June 2013. In the first step, the samples were subjected to a preliminary sieving to eliminate big particles. In the second step, sawdust was treated according to the physical methods previously described (Elbariji et al. 2006; Vaishya and Prasad 1991), and then sieved through a $500 \mu \mathrm{m}$ mesh sieve and washed several times with distilled water to remove hydrosoluble impurities. Finally, the samples were dried at $40{ }^{\circ} \mathrm{C}$ to constant weight and preserved in an impermeable flask to limit potential microbiological degradation.

The Sawdust was analyzed with sieve vibrator [ $R E T S$ CH type AS 200) for the granulometry determination, FTIR spectrophotometer (ALPHA Brucker), X-ray diffraction (Xpert Pro X-ray diffractometer] and fluorescence (7221/ SIEMENS SRX 3400).

Point of zero charge of pine sawdust $\left(\mathrm{pH}_{\mathrm{pzc}}\right)$

The pHpzc of the adsorbent material is an important parameter; it determines the $\mathrm{pH}$ at which the adsorbent surface has net electrical neutrality. The determination of the pHpzc of the used pine sawdust was as follows: a series of $20 \mathrm{~mL}$ of $0.01 \mathrm{~mol} / \mathrm{L} \mathrm{NaCl}$ solutions were poured in closed conical flasks, the $\mathrm{pH}$ was adjusted in the range of $0.5-10$. Then, in each solution, $0.2 \mathrm{~g}$ of adsorbent was soaked under agitation at room temperature and the final $\mathrm{pH}$ was measured after $24 \mathrm{~h}$. The pHpzc is defined as the point where the curve pHinitial versus pHfinal crosses the line pHinitial $=$ pHfinal.

\section{Adsorption kinetic experiments}

The adsorption kinetics were carried out in static regime; batch experiments were conducted at a controlled temperature by adding a known weight of sawdust into a number of $500 \mathrm{~mL}$ glass stoppered conical flasks on magnetic shaker.

Adsorption experiments included selection of sawdust type and the effect of the following parameters on the pine sawdust adsorption capacity, namely granulometry of sawdust powder, contact time, solid/liquid ratio i.e. adsorbent dosage, stirring speed, temperature, electrolyte concentration, initial $\mathrm{Pb}(\mathrm{II})$ concentration and initial solution $\mathrm{pH}$.

As previously mentioned, three types of sawdust were used for lead ions adsorption tests namely pine, beech and fir sawdust. The experiments were carried out at $25{ }^{\circ} \mathrm{C}$ and pH $5.45 \pm 0.05$ by shaking $5 \mathrm{~g}$ of adsorbent and $100 \mathrm{mg} / \mathrm{L}$ $\mathrm{Pb}$ (II) solution at $500 \mathrm{rpm}$. The selected sawdust i.e. pine sawdust was sieved in three ranges of mean diameters and then the adsorption kinetics were conducted in the same experimental conditions.

Therefore, the next tests were conducted using pine sawdust with particle size $(d)$ inferior to $500 \mu \mathrm{m}$. So, the effect of contact time was determined at $25{ }^{\circ} \mathrm{C}$ by mixing $5 \mathrm{~g}$ of adsorbent with $100 \mathrm{mg} / \mathrm{L} \mathrm{Pb}$ (II) solution at $500 \mathrm{rpm}$ for different time $(1,2,5,10,15,20,25,30,40,50,60,90$, $120,150 \mathrm{~min})$. The effect of adsorbent dosage i.e. sawdust/ liquid ratio was conducted at $25{ }^{\circ} \mathrm{C}$ by adding different 
amounts of sawdust $(5,10,20$ and $30 \mathrm{~g} / \mathrm{L})$ at $100 \mathrm{mg} / \mathrm{L}$ $\mathrm{Pb}$ (II) solutions at $\mathrm{pH} 5.45 \pm 0.05$ stirred at $500 \mathrm{rpm}$ for $90 \mathrm{~min}$. To investigate the effect of initial $\mathrm{pH}$ at $25^{\circ} \mathrm{C}, 5 \mathrm{~g}$ of adsorbent was mixed with $100 \mathrm{mg} / \mathrm{L} \mathrm{Pb}$ (II) solution at $500 \mathrm{rpm}$ and at various $\mathrm{pH}$ values ranging from 2.0 to 6.0 for $90 \mathrm{~min}$. Also, experiments were carried out by shaking $5 \mathrm{~g}$ of adsorbent $100 \mathrm{mg} / \mathrm{L} \mathrm{Pb}$ (II) solution at different stirring speed $(N=500,1,000$ and $1,500 \mathrm{rpm})$ and at various temperatures $\left(23,40,50\right.$ and $\left.60{ }^{\circ} \mathrm{C}\right)$. The effect of initial $\mathrm{Pb}$ (II) concentration was conducted by adding $5 \mathrm{~g}$ of sawdust at $\mathrm{Pb}$ (II) solutions of various concentrations (50, 100,150 and $200 \mathrm{mg} / \mathrm{L}$ ) for $90 \mathrm{~min}$ at $25^{\circ} \mathrm{C}$. Finally, some experiments were carried out at $25^{\circ} \mathrm{C}$ by mixing $5 \mathrm{~g}$ of sawdust with $100 \mathrm{mg} / \mathrm{L} \mathrm{Pb}$ (II) solution containing 5, 10, 15 and $30 \mathrm{~g} / \mathrm{L}$ of $\mathrm{NaCl}$ at $500 \mathrm{rpm}$.

\section{Isotherm adsorption study}

For isotherm studies, adsorption experiments were carried out by shaking $5 \mathrm{~g}$ of sawdust samples with $500 \mathrm{ml}$ of $\mathrm{Pb}$ (II) solution at a concentration range $50-300 \mathrm{mg} / \mathrm{L}$ at a fixed temperature in a thermostated shaker bath for $90 \mathrm{~min}$. At equilibrium the suspension was filtered and the metal solution was analyzed.

\section{Metal analysis}

For all experiments and at different intervals time, suspensions $(10 \mathrm{~mL})$ were withdrawn and filtered through filter paper (Sortorius No. 389). The $\mathrm{Pb}(\mathrm{II})$ concentrations in the filtrates were determined by atomic absorption analysis at $217 \mathrm{~nm}$ using Perkin Elmer-280 spectrophotometer; the calibration curves were established before each kinetic using standards at 0.5, 1, 2, 4, 6, 8, 10 and $20 \mathrm{mg} / \mathrm{L}$ of $\mathrm{Pb}$ (II) solutions and where the adsorption coefficient was equal to $0.012 \mathrm{~L} / \mathrm{mg}$. The sorption efficiency is expressed in percentage by the following equation:

Adsorption efficiency $\%=\frac{\left(C_{0}-C_{\mathrm{r}}\right)}{C_{0}} \times 100$

where $C_{0}$ and $C_{\mathrm{r}}(\mathrm{mg} / \mathrm{L})$ are respectively the initial and residual concentrations of $\mathrm{Pb}$ (II) ions.

For isotherms, the amount of ions adsorbed per mass unit of sawdust $(\mathrm{mg} / \mathrm{g})$ at equilibrium was evaluated using the following expression:

$q_{\mathrm{e}}=\frac{\left(C_{0}-C_{\mathrm{e}}\right) V}{m}$

where $C_{\mathrm{e}}(\mathrm{mg} / \mathrm{L})$ is the concentration of $\mathrm{Pb}$ (II) at equilibrium, $V(\mathrm{~L})$ is the synthetic effluent volume and $m(\mathrm{~g})$ is the adsorbent mass.

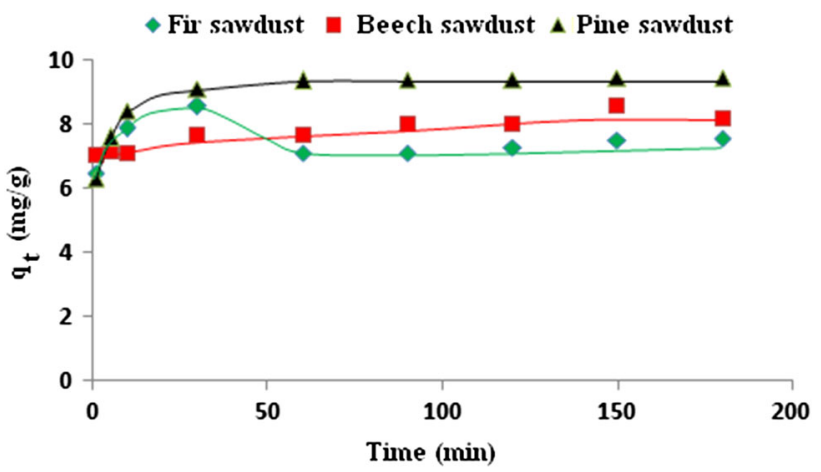

Fig. 1 Lead adsorption kinetics for pine, beech and fir sawdusts

\section{Results and discussion}

Selection of sawdust type

In this section, the results of the $\mathrm{Pb}$ (II) adsorption on the three types of sawdust were compared, and the amount of ions adsorbed per mass unit of sawdust as a function of times are illustrated in Fig. 1. The plots showed that the rate of $\mathrm{Pb}$ removal is higher at the kinetic beginning and the adsorption equilibrium is achieved after $90 \mathrm{~min}$ of contact time, for the three types of sawdust. However, the lead adsorption efficiency on pine sawdust was significantly higher $(94 \%)$ than that on beech sawdust $(87 \%)$ and fir sawdust $(76 \%)$. As known, beech and fir sawdust are hardwood with a higher density, since they were not subject to chemical treatment, their capacity of metal adsorption is lower than that the pine sawdust. So, for the further tests we have selected the pine sawdust.

\section{Characterization of the pine sawdust}

The chosen sawdust i.e. pine sawdust was analyzed by infrared spectroscopy as shown in Fig. 2. The FTIR spectrum presented a broad band located around $3,328 \mathrm{~cm}^{-1}$ which is assigned to $\mathrm{O}-\mathrm{H}$ stretching vibrations of hydrogen bonded hydroxyl groups. In fact, the hydroxyl groups are present in the primary components of wood: cellulose, hemicelluloses and lignin (Argun et al. 2007; HidalgoVÁzquez et al. 2011). The observed bands at 2,922 and $1,689 \mathrm{~cm}^{-1}$ correspond respectively to the $\mathrm{C}-\mathrm{H}$ and $\mathrm{C}=\mathrm{O}$ stretching vibrations (Haider and Park 2009; Khattria and Singh 2009; Nasir et al. 2007). The strong band at $1,024 \mathrm{~cm}^{-1}$ is attributed to $\mathrm{C}-\mathrm{O}$ vibration specific to the lignin component in wood sawdust. The Fig. 3 showed the RX-diffraction analysis of pine sawdust, the diffractogram indicates peaks at $22.3^{\circ}$ and $34.5^{\circ}$ and a broad peak around $16^{\circ}$ which characterize the semi-crystalline cellulose structure (Cheng et al. 2011). The results of the quantitative chemical composition of pine sawdust before and after 
Fig. 2 Infrared spectrum of pine sawdust

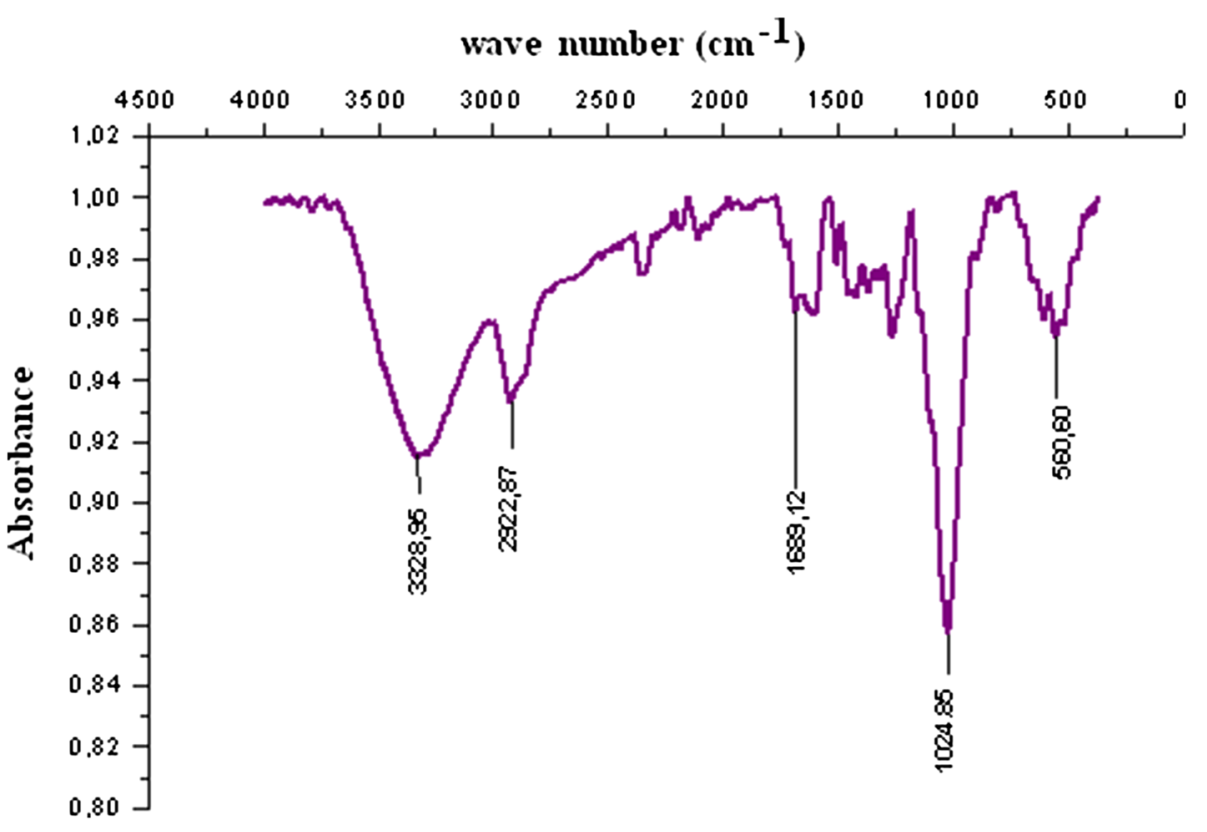

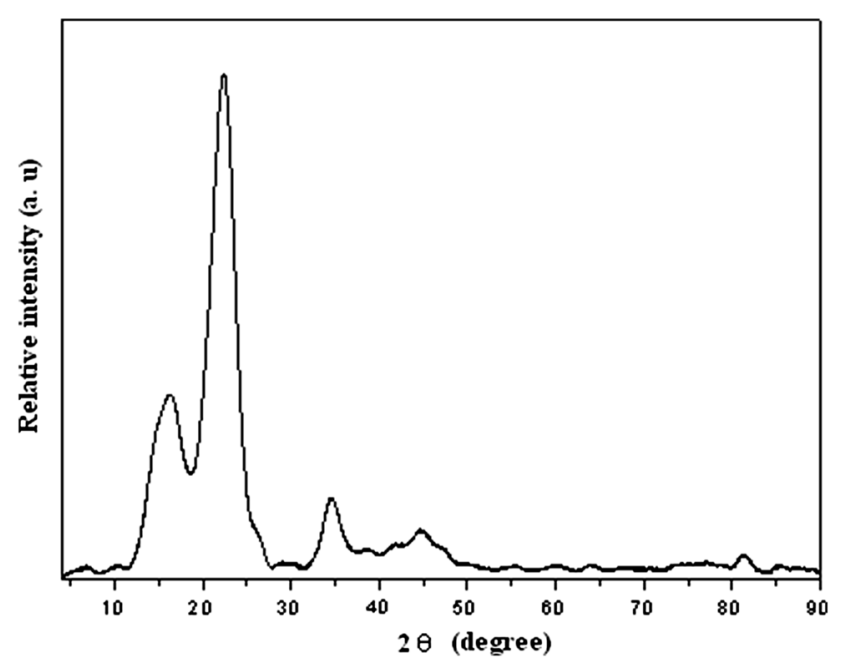

Fig. 3 X-ray diffractogram of pine sawdust adsorption experiment obtained by X-ray fluorescence are reported in Table 1. The results revealed the presence of $\mathrm{PbO}$ in pine sawdust after the effluent treatment. As well, the FXR spectra confirmed the $\mathrm{Pb}$ adsorption by pine sawdust (Fig. 4).

Adsorption kinetic tests and process variables optimization

Effect of pine sawdust granulometry

Three ranges of mean diameters of sawdust powder i.e. $500<d_{1}<800 \mu \mathrm{m}, \quad 200<d_{2}<500 \mu \mathrm{m} \quad$ and $d_{3}<200 \mu \mathrm{m}$ were tested and compared, and the results of the adsorption efficiency versus time are plotted in Fig. 5. We noted that in the earlier stage, the adsorption efficiency increases as mean diameter of sawdust decreases; the

Table 1 Elemental composition of the native and used pine sawdust: before and after effluent treatment

\begin{tabular}{|c|c|c|c|c|c|c|c|c|c|}
\hline \multirow[t]{2}{*}{ Pine sawdust } & \multicolumn{9}{|c|}{ Elemental composition in oxides form (\%) } \\
\hline & $\mathrm{SiO}_{2}$ & $\mathrm{Al}_{2} \mathrm{O}_{3}$ & $\mathrm{Fe}_{2} \mathrm{O}_{3}$ & $\mathrm{CaO}$ & $\mathrm{MgO}$ & $\mathrm{MnO}$ & $\mathrm{Na}_{2} \mathrm{O}$ & $\mathrm{K}_{2} \mathrm{O}$ & $\mathrm{P}_{2} \mathrm{O}_{5}$ \\
\hline Before & 0.079 & 0.040 & 0.010 & 0.377 & 0.079 & 0.002 & 0.035 & 0.031 & 0.021 \\
\hline \multirow[t]{2}{*}{ After } & 0.106 & 0.065 & 0.014 & 0.617 & 0.060 & - & 0.088 & 0.015 & 0.025 \\
\hline & $\mathrm{TiO}_{2}$ & $\mathrm{Cr}_{2} \mathrm{O}_{3}$ & $\mathrm{SO}_{3}$ & $\mathrm{ZrO}_{2}$ & $\mathrm{SrO}$ & $\mathrm{Rb}_{2} \mathrm{O}$ & $\mathrm{PbO}$ & $\mathrm{ZnO}$ & $\mathrm{CuO}$ \\
\hline Before & - & - & 0.037 & - & - & - & - & - & 0.007 \\
\hline \multirow[t]{2}{*}{ After } & - & - & 0.040 & - & - & - & 0.176 & - & 0.017 \\
\hline & $\mathrm{NiO}$ & $\mathrm{BaO}$ & PAF & Total & & & & & \\
\hline Before & 0.004 & - & 99.27 & 99.99 & & & & & \\
\hline After & 0.002 & - & 98.70 & 99.92 & & & & & \\
\hline
\end{tabular}




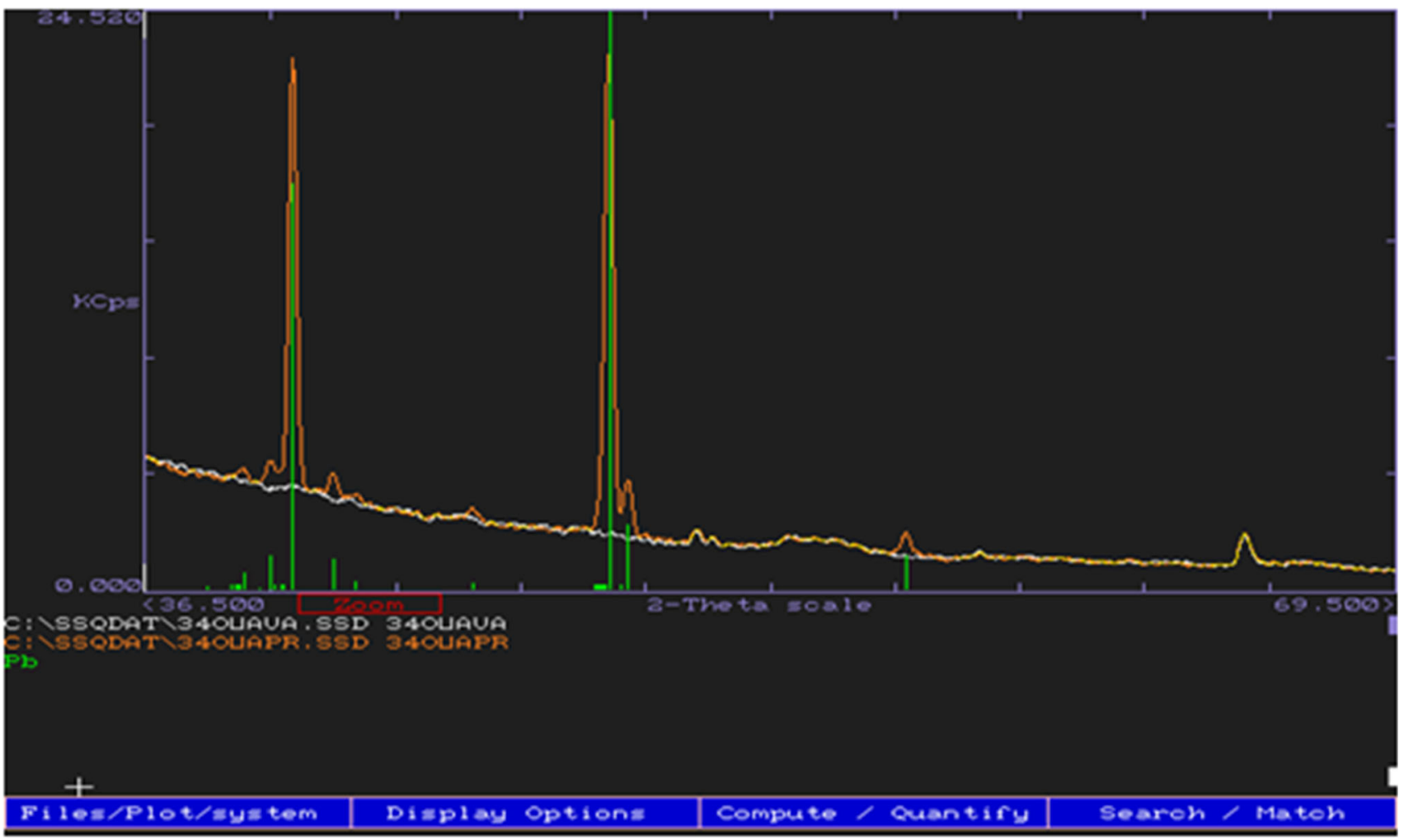

Fig. 4 FXR spectra of pine sawdust before (in white color) and after (in orange color) adsorption experiment

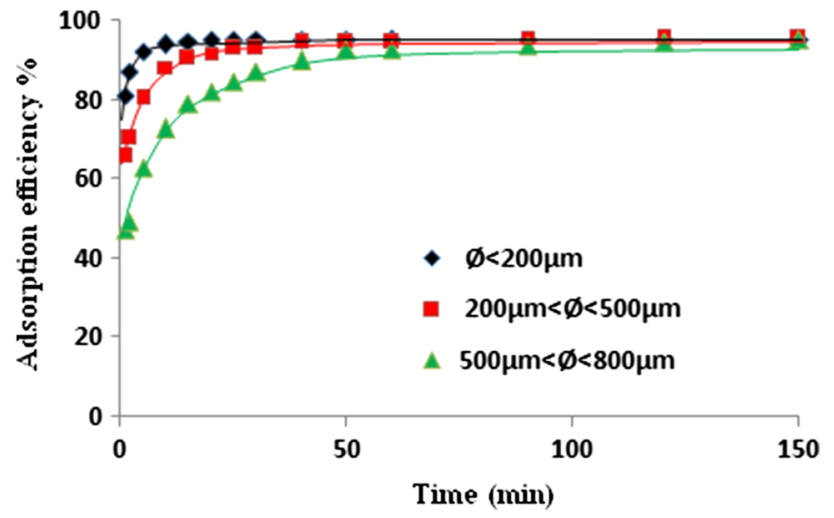

Fig. 5 Effect of sawdust granulometry on $\mathrm{Pb}(\mathrm{II})$ adsorption kinetics $\left(C_{0}=100 \mathrm{mg} / \mathrm{L}, \mathrm{pH} 5.40,500 \mathrm{rpm}\right)$

remark is common since the specific surface of sawdust increases as the mean diameter decreases for non-porous particles, consequently the metal adsorption is favored (Khattria and Singh 2009).

For the small particles $(d<200 \mu \mathrm{m})$, the maximum of adsorption efficiency was achieved in little time in about $20 \mathrm{~min}$; however, the adsorption equilibrium time was $90 \mathrm{~min}$ for sawdust particles with mean diameter $200<d<500 \mu \mathrm{m}$ and it was the higher $(150 \mathrm{~min})$ for the big particles $(500<d<800 \mu \mathrm{m})$. In fact, for the same adsorbent dosage, when the particle size is small, the total

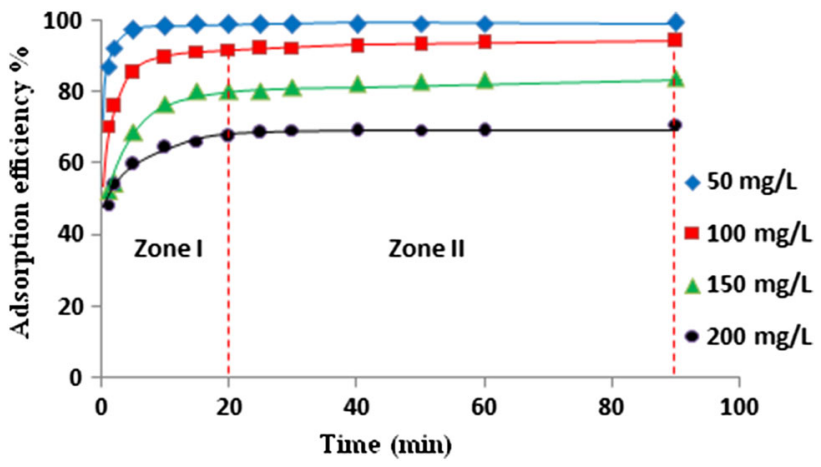

Fig. 6 Contact time and effect of initial concentration of $\mathrm{Pb}(\mathrm{II})$ on the adsorption efficiency

surface contact of adsorbent becomes bigger and then the adsorption phenomenon is favored. The effect of sawdust granulometry on divalent metal adsorption has been also investigated by Ajmal et al. (1998) and these results are in agreement with some previous studies (LiewAbdullah et al. 2005; Me Convey and Me Kay 1985; Shukla et al. 2002).

As well, we noted that whatever the particle size, $75 \%$ of $\mathrm{Pb}$ (II) was removed at $90 \mathrm{~min}$ of contact time. Since the elimination of the small particles of sawdust $(d<200 \mu \mathrm{m})$ from the aqueous solution is more difficult and expensive at the industrial scale, we have chosen sawdust with mean diameter of particles $200<d<500 \mu \mathrm{m}$ for a detailed study of lead adsorption. 


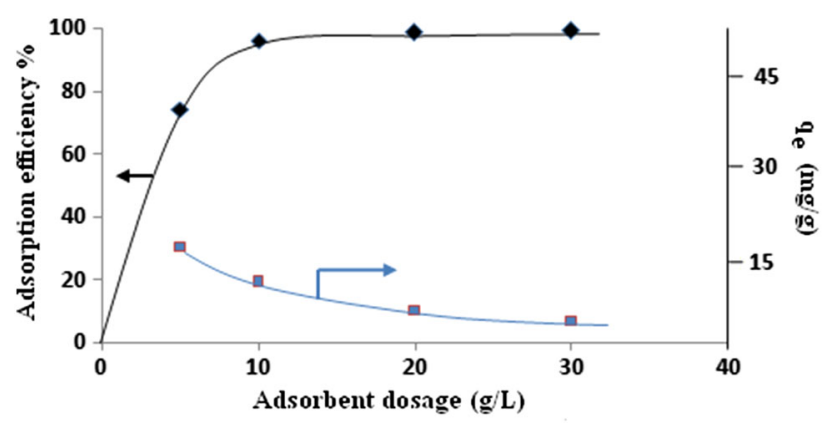

Fig. 7 Variation of equilibrium adsorption efficiency of $\mathrm{Pb}$ (II) ion as a function of adsorbent dosage $\left(\mathrm{pH} 5.45 ; 500 \mathrm{rpm}, C_{0}=100 \mathrm{mg} / \mathrm{L}\right.$, $d<500 \mu \mathrm{m})$

\section{Contact time and Effect of initial Pb(II) concentration}

Some experiments were carried out using different initial concentration of $\mathrm{Pb}(\mathrm{II})$ and at a fixed sawdust/liquid volume ratio $(10 \mathrm{~g} / \mathrm{L})$. The plots of adsorption efficiency as a function of time allowed to the appropriate contact time between sawdust and ion solution (Fig. 6).

The results showed that for the low concentration of adsorbate $(50 \mathrm{mg} / \mathrm{L})$, the adsorption equilibrium was rapidly achieved; in 20 min approximately where a total ion adsorption was noticed (99\%). Also, we noted that 94 and $84 \%$ of $\mathrm{Pb}$ ions were adsorbed when their initial concentrations were respectively 100 and $150 \mathrm{mg} / \mathrm{L}$. Nevertheless, at the high concentration especially for $200 \mathrm{mg} / \mathrm{L} \mathrm{Pb}$ (II) solution, only $70 \%$ of adsorption efficiency was achieved after $90 \mathrm{~min}$ of contact time. We concluded that $10 \mathrm{~g} / \mathrm{L}$ of pine sawdust is practically the sufficient adsorbent dosage for the lead adsorption from $100 \mathrm{mg} / \mathrm{L} \mathrm{Pb}$ (II) solution.

In Fig. 6, the corresponding plot of $100 \mathrm{mg} / \mathrm{L} \mathrm{Pb}$ (II) solution showed that the $\mathrm{Pb}$ (II) removal is rapid in zone I, so at the beginning; certainly the surface area of sawdust is higher in the first time and consequently the adsorption is favored. In zone II, the surface area diminished because the site became exhausted and the adsorption started in pores; consequently the metal adsorption became slow and weak. The maximum rate of $\mathrm{Pb}$ (II) adsorption was achieved after 90 min of stirring. Then, for the subsequent experiments the equilibrium time was maintained at $90 \mathrm{~min}$. We noticed that the same contact time was observed for eucalyptus sawdust by Hamane et al. studies (Hamane and Bendjama 2007).

\section{Effect of adsorbent dosage}

These experiments gave the effect of solid/liquid ratio $(r)$ i.e. sawdust mass (g)/effluent volume (L) on the adsorption efficiency at equilibrium (Fig. 7). The results demonstrated, for the selected sawdust and in presence of $100 \mathrm{mg} / \mathrm{L}$ of initial lead concentration that the lead adsorption efficiency did not change significantly for a

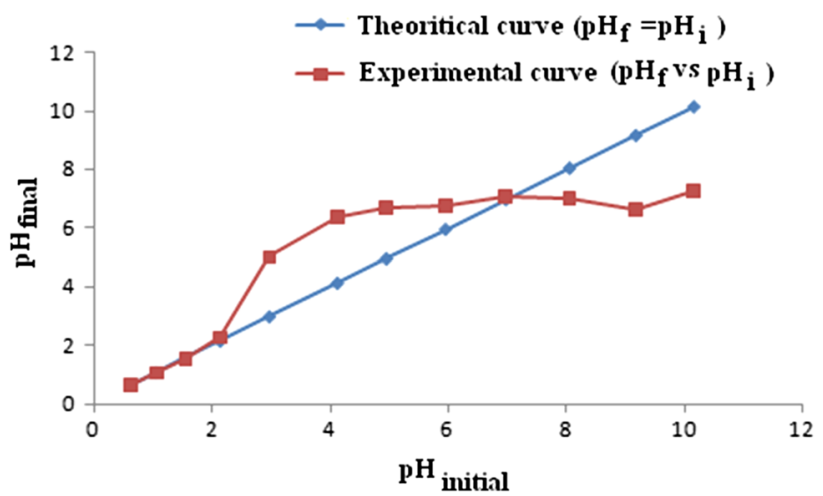

Fig. 8 Determination of $\mathrm{pH}_{\mathrm{pzc}}$ of pine sawdust

solid/liquid ratio higher than $20 \mathrm{~g} / \mathrm{L}$. In fact, the adsorption efficiency obtained with $5 \mathrm{~g} / \mathrm{L}$ of solid/liquid ratio was $74 \%$; however, for 10,20 and $30 \mathrm{~g} / \mathrm{L}$ it was 96,98 and $99 \%$ respectively. The results are in agreement with similar previous study for heavy metal adsorption (Bouchemal and Achour 2007; Fiset et al. 2001). However, the adsorption capacity $\left(q_{\mathrm{e}}\right)$ decreases as adsorbent dosage increases (Fig. 7); the remark is common because in this range of adsorbent dosage, the adsorption efficiency didn't change significantly and since the " $q$ " value symbolize the mass of metal adsorbed per unit mass of adsorbent, and when the weight of adsorbent is higher, the amount of $\mathrm{Pb}$ (II) ions adsorbed per unit mass of adsorbent $(q)$ must be lower.

\section{Effect of initial $p H$}

The initial $\mathrm{pH}$ value of solution is an important factor affecting the metal sorption because it may change the surface charge of the adsorbent ( $\mathrm{Gad}$ et al. 2013; Fiset et al. 2001); so, it is necessary to determine the point of zero charge of the used adsorbent. As shown in Fig. 8, the $\mathrm{pH}_{\mathrm{pzc}}$ which corresponds to the point of intersection of the experimental curve $\left(\mathrm{pH}_{\mathrm{f}}\right.$ versus $\left.\mathrm{pH}_{\mathrm{i}}\right)$ with the theoretical linear plot $\left(\mathrm{pH}_{\mathrm{f}}=\mathrm{pH}_{\mathrm{i}}\right)$ is equal to 7 , indicating that below this $\mathrm{pH}$ the sawdust particles acquire positive charge whereas above this $\mathrm{pH}$ a sawdust surface is negatively charged. We noticed that many types of sawdust had $\mathrm{pH}_{\mathrm{pzc}}$ around 7 (Singh et al. 2011; Ofojama and Ho 2008).

Concerning the biosorption of $\mathrm{Pb}(\mathrm{II})$, it could not be carried out beyond $\mathrm{pH} 6$ due to its potential precipitation in $\mathrm{Pb}(\mathrm{OH})_{2}$ form at higher $\mathrm{pHs}$ and therefore, for the present study, the effect of initial $\mathrm{pH}$ solution was analyzed only over the range from 2 to 6 .

$\mathrm{The} \mathrm{Pb}(\mathrm{II})$ removal was tested at three $\mathrm{pH}$ values of the synthetic effluent; in this investigation, it was observed that the $\%$ of $\mathrm{Pb}$ (II) removal increases as $\mathrm{pH}$ of the solution increases where good linear feet was observed with the three $\mathrm{pH}$ values. 
In fact, at low $\mathrm{pH}(2.04)$, the adsorption efficiency at equilibrium was $84.9 \%$. However, at $\mathrm{pH} 4.07$ and 6.0 respectively, 92.8 and $96.9 \%$ of $\mathrm{Pb}$ was removed from the synthetic effluent $\left(C_{0}=100 \mathrm{mg} / \mathrm{L}\right)$. The same observation was reported in some papers for the lead adsorption onto different sawdust (Marin and Ayele 2002; Taty-Costodes et al. 2003; Gad et al. 2013).

This phenomenon can be explained by the surface charge of the adsorbent and the $\mathrm{H}^{+}$ions present in the solution. In fact, at $\mathrm{pH}<\mathrm{pH}_{\mathrm{pzc}}$, sawdust becomes positively charged due to the adsorption of $\mathrm{H}^{+}$ions. Thus, the electrostatic force of repulsion between sawdust and $\mathrm{Pb}$ (II) is prominent at low $\mathrm{pH}$. According to the $\mathrm{pHpzc}$ of the adsorbent $(\mathrm{pHpzc}=7)$, at the $\mathrm{pH}$ of the adsorbate solution chosen (5.5-6.0), the superficial charge of the adsorbent is still positive and it is not so much as at $\mathrm{pH} \mathrm{2;} \mathrm{this} \mathrm{could}$ explain the low sorption capacity of the adsorbent. In addition, the concentration of $\mathrm{H}^{+}$is high at low $\mathrm{pH}$ and they compete with $\mathrm{Pb}$ (II) in the solution for the active sites; therefore, the adsorption was low at low $\mathrm{pH}$. While, as the $\mathrm{pH}$ increases, the adsorption surface becomes less positive and therefore, electrostatic attraction between the metal ions and sawdust surface is likely to be increased. Also, increasing the $\mathrm{pH}$ reduces the competition between the $\mathrm{H}^{+}$ and $\mathrm{Pb}$ (II) and then the $\mathrm{Pb}$ (II) uptake became more favored (Hamane and Bendjama 2007). Subsequently pH 5.5 was chosen as optimal $\mathrm{pH}$ for all our studies.

\section{Effect of temperature and stirring speed}

Adsorption kinetics of $\mathrm{Pb}$ (II) onto pine sawdust were carried out at various temperatures $\left(23,40,50\right.$ and $\left.60^{\circ} \mathrm{C}\right)$. The results showed that at the earlier stage of kinetics i.e. under the first $10 \mathrm{~min}$, the lead removal rate increased as temperature increased. While, at equilibrium (after $90 \mathrm{~min}$ ), we noted that the adsorption efficiency is conversely proportional to the temperature; this effect is clear in Fig. 9 where the amount of $\mathrm{Pb}$ (II) ions adsorbed per mass unit of sawdust $\left(q_{\mathrm{e}}\right)$ was plotted as function of temperature. So the lead adsorption is an exothermic phenomenon since it is favored at low temperature (Jianga et al. 2009; Kim et al. 1999). This fact can be explained either by the higher mobility of ions at high temperature or by the destruction or solubilisation of adsorption sites. At high temperature and due to the large kinetic energy of particles, in the earlier time the possibility of collision between metal and adsorbent sites is higher; however, when reaching equilibrium the probability of collision and consequently fixation of metal ions become unprivileged because majority of sites on surface are occupied. As well, it was observed that at high temperature, adsorption sites can be subject to destruction or solubilization like the

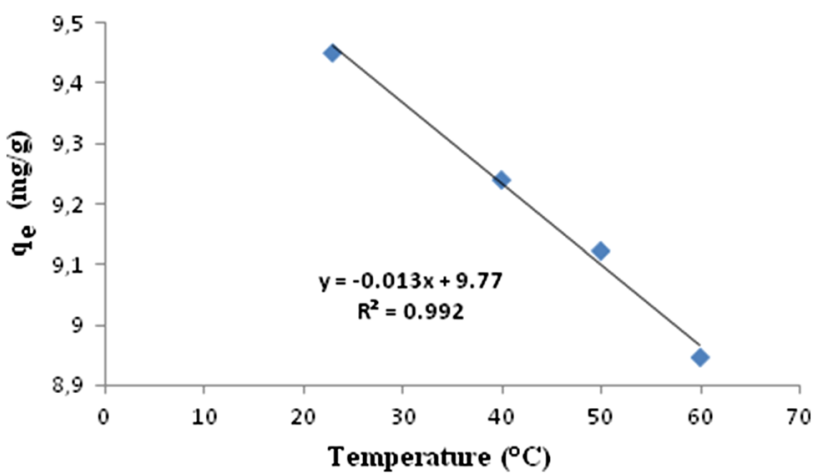

Fig. 9 Effect of temperature on the amount of $\mathrm{Pb}(\mathrm{II})$ ions adsorbed per mass unit of sawdust at equilibrium $\left(\mathrm{pH} 5.45, C_{0}=100 \mathrm{mg} / \mathrm{L}\right.$, $N=500 \mathrm{rpm}, r=10 \mathrm{~g} / \mathrm{L}$ )

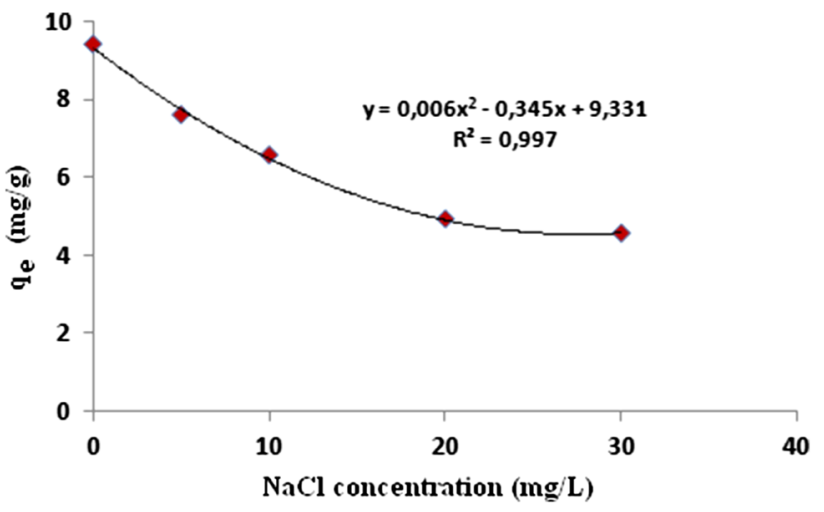

Fig. 10 Effect of electrolyte $(\mathrm{NaCl})$ concentration on the amount of

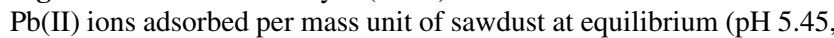
$C_{0}=100 \mathrm{mg} / \mathrm{L}, N=500 \mathrm{rpm}, r=10 \mathrm{~g} / \mathrm{L}$ )

tannin onto sawdust as reported in Fiset et al. (2001) revue and so the adsorption phenomenon is disfavored.

For the present results, a best linear relationship between $q_{\mathrm{e}}$ and temperature was obtained with 0.992 of coefficient of determination. For other effluents, temperature can possess positive effect and the adsorption process becomes endothermic (Zou et al. 2013; Gad et al. 2013).

To investigate the effect of stirring speed on the metal removal, the kinetics were conducted under different stirring speed; 500, 1,000 and 1,500 rpm. The results demonstrated that the stirring speed didn't affect significantly the adsorption efficiency in the present conditions.

\section{Effect of electrolyte concentration}

The $\mathrm{Pb}(\mathrm{II})$ removal was also studied in presence of 5,10 , 15 and $30 \mathrm{~g} / \mathrm{L}$ of $\mathrm{NaCl}$, the amount of ions adsorbed per mass unit of pine sawdust at equilibrium as a function of electrolyte concentration is given in Fig. 10. We noted that the adsorption efficiency is unprivileged in salty effluents. In fact, the sodium ions are smaller than lead ones and consequently they are preferably fixed onto adsorbent sites 
than metal ions, the same effect was reported by Gupta et al. (2001) for heavy metal adsorption on red-mud.

\section{Adsorption isotherms}

The study of adsorption isotherms is imperative to describe the adsorption mechanism and so the interaction of metal ion on the adsorbent surface. The previous experiments permitted as to determine the optimal conditions relating to adsorbent and adsorbate, for the lead removal using the available pine sawdust: $\mathrm{pH} 5.42, N=500 \mathrm{rpm}, r=10 \mathrm{~g} /$ $\mathrm{L}, d<500 \mu \mathrm{m}$, without $\mathrm{NaCl}$, contact time $90 \mathrm{~min}$.

In these conditions and by varying metal concentration from 50 to $300 \mathrm{mg} / \mathrm{L}$, the adsorption isotherm of $\mathrm{Pb}$ (II) was studied at $23 \pm 2{ }^{\circ} \mathrm{C}$; the amount of adsorbate at equilibrium per unit mass of adsorbent as a function of adsorbate concentration is given in Fig. 11.

According to Giles et al.'s classification (Giles et al. 1960; Chitour 2004), in this case, adsorption isotherm of $\mathrm{Pb}$ (II) ions onto the used pine sawdust is "L" type. The equilibrium data were analyzed by considering the Langmuir and Freundlich isotherm models.

\section{Freundlich isotherm model}

The empirical Freundlich isotherm model can describe the adsorption on heterogeneous surfaces. The linear form of Freundlich isotherm equation is:

$\operatorname{Ln} q_{\mathrm{e}}=\ln K_{\mathrm{F}}+\left(\frac{1}{n}\right) \ln C_{\mathrm{e}}$

where, $q_{\mathrm{e}}$ is the amount of metal ions adsorbed per unit weight of sawdust $(\mathrm{mg} / \mathrm{g}), C_{\mathrm{e}}$ is the equilibrium concentration of the metal ion in the equilibrium solution $(\mathrm{mg} / \mathrm{L})$, $K_{\mathrm{F}}$ is constant characteristic of the relative adsorption

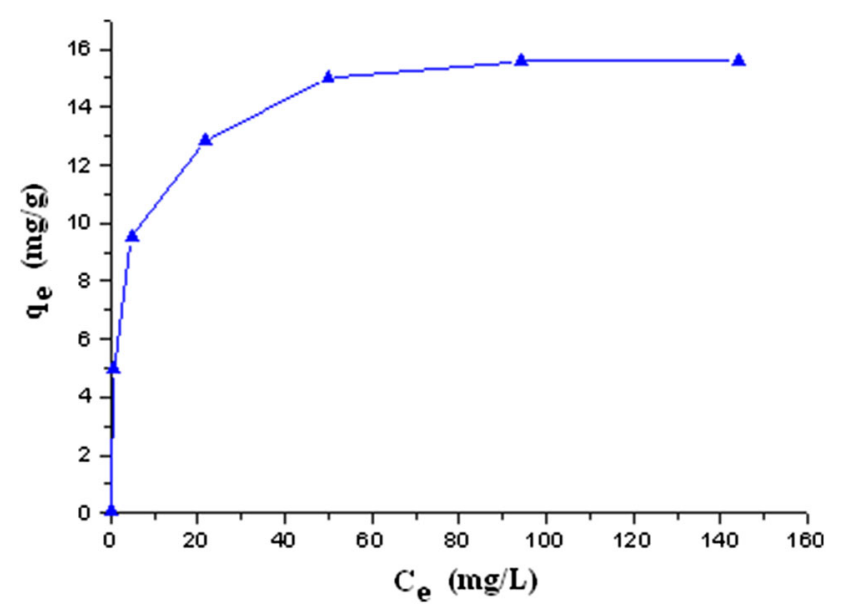

Fig. 11 Adsorption isotherm of $\mathrm{Pb}$ ions onto pine sawdust

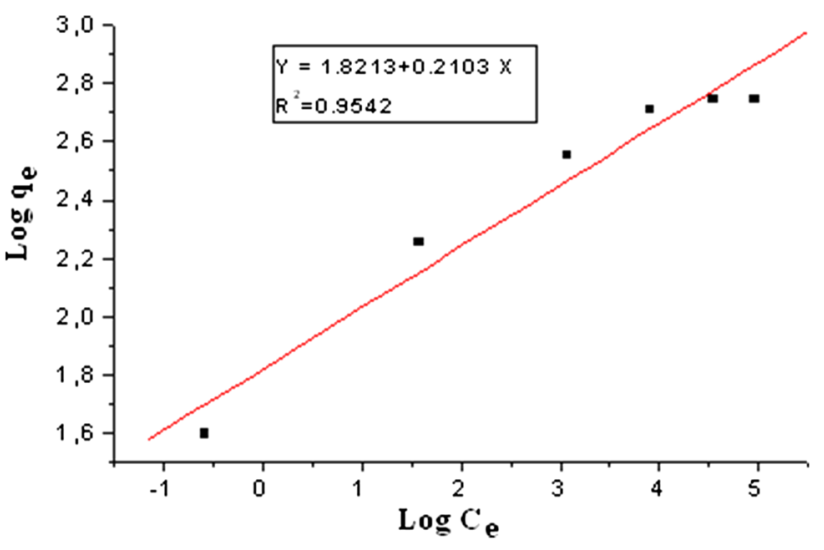

Fig. 12 Freundlich plot of $\mathrm{Pb}(\mathrm{II})$ adsorption results onto pine sawdust

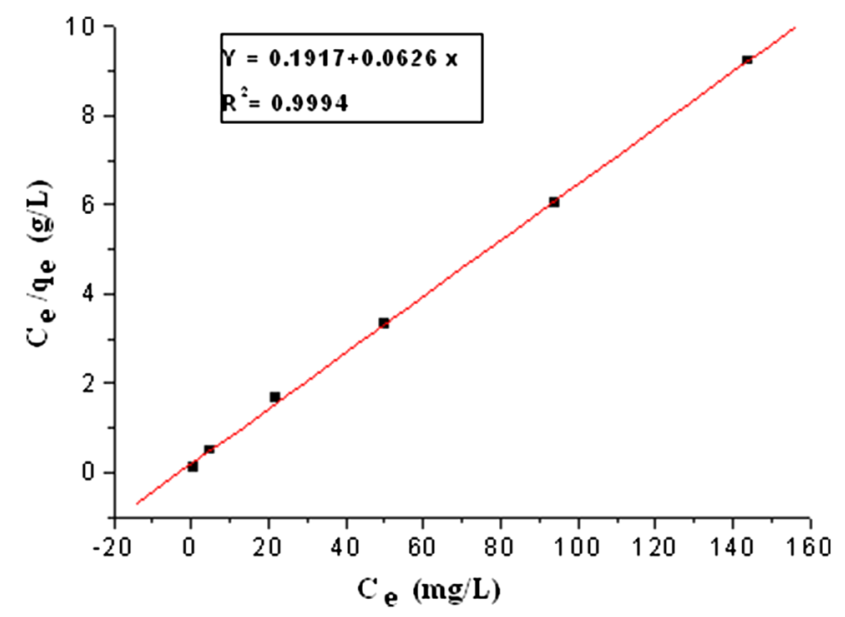

Fig. 13 Langmuir plot of $\mathrm{Pb}(\mathrm{II})$ onto pine sawdust

capacity of adsorbent and $1 / n$ is the indicative constant of the sorption process intensity. The model has been tested and the obtained plot is given in Fig. 12.

Langmuir isotherm model

The adsorption results of $\mathrm{Pb}(\mathrm{II})$ onto pine sawdust were fitted in Langmuir equation :

$\frac{C_{\mathrm{e}}}{q_{\mathrm{e}}}=\left(\frac{1}{Q_{0} b}\right)+\frac{C_{\mathrm{e}}}{Q_{0}}$

where $C_{\mathrm{e}}$ is the equilibrium concentration $(\mathrm{mg} / \mathrm{L}), q_{\mathrm{e}}$ is the amount of $\mathrm{Pb}(\mathrm{II})$ adsorbed at equilibrium time $(\mathrm{mg} / \mathrm{g})$ and $Q_{0}$ and $b$ are Langmuir constants related to adsorption capacity and energy of adsorption. The linearized Langmuir plot of $C_{\mathrm{e}} / q_{\mathrm{e}}$ versus $C_{\mathrm{e}}$ is shown in Fig. 13 .

The additional analysis of the Langmuir equation can be made on the basis of the dimensionless equilibrium parameter $R_{\mathrm{L}}$ (Hall et al. 1966). For a favorable adsorption, the value of $R_{\mathrm{L}}$ is between 0 and 1 , while $R_{\mathrm{L}}>1$ represents 
Table 2 Freundlich and Langmuir parameters for $\mathrm{Pb}(\mathrm{II})$ adsorption isotherms

\begin{tabular}{|c|c|c|c|c|c|}
\hline \multicolumn{3}{|c|}{ Freundlich isotherm model } & \multicolumn{3}{|c|}{ Langmuir isotherm model } \\
\hline $\begin{array}{l}1 / n(\mathrm{~L} / \\
\mathrm{g})\end{array}$ & $\begin{array}{l}K_{\mathrm{F}}\left(\mathrm{mg}^{1-1 / n} \mathrm{~L}^{1 / n}\right. \\
\left.\mathrm{g}^{-1}\right)\end{array}$ & $R^{2}$ & $\begin{array}{l}Q_{0}(\mathrm{mg} / \\
\mathrm{g})\end{array}$ & $\begin{array}{l}b(\mathrm{~L} / \\
\mathrm{mg})\end{array}$ & $R^{2}$ \\
\hline 0.2103 & 6.1800 & 0.9542 & 15.9744 & 0.3265 & 0.9994 \\
\hline
\end{tabular}

$R^{2}$ coefficient of determination

an unfavorable adsorption, $R_{\mathrm{L}}=1$ represents the linear adsorption, and if $R_{\mathrm{L}}=0$ the adsorption operation is irreversible. The $R_{\mathrm{L}}$ value can be calculated by Eq. (5):

$R_{L}=\frac{1}{1+b C_{0}}$

The Freundlich and Langmuir parameters are given in Table 2. The results demonstrated that the $\mathrm{Pb}$ (II) adsorption on the selected pine sawdust is well fitted by Langmuir model where the coefficient of determination is equal to 0.9994 and the adsorption capacity is about 16 which proved a good affinity and monolayer adsorption of $\mathrm{Pb}$ (II) onto sawdust adsorbent.

Furthermore, the dimensionless parameter $R_{\mathrm{L}}$, is found in the range of 0.010 and $0.0577\left(0<R_{\mathrm{L}}<1\right)$ which confirms the favorable adsorption process for $\mathrm{Pb}$ (II) using pine sawdust.

\section{Conclusion}

In this study, available pine sawdust was highlighted by a number of adsorption tests of lead ions in various experimental conditions. Firstly, a comparison between three types of sawdust; pine, beech and fir sawdust's which had respectively 94,87 and $75 \%$ of adsorption efficiency, permitted to select the good adsorbent for lead removal from the synthetic effluent.

Secondly, the optimization of experimental conditions leads to the following conclusions for pine sawdust with particle size lower than $500 \mu \mathrm{m}$ : $90 \mathrm{~min}$ is a sufficient contact time for $96 \%$ of $\mathrm{Pb}(\mathrm{II})$ removal from synthetic effluent at initial concentration of $100 \mathrm{mg} / \mathrm{L}$ and at optimum pH 5.5 and using $10 \mathrm{~g} / \mathrm{L}$ of sawdust weight/volume of liquid effluent ratio $(r)$. Almost total adsorption of $\mathrm{Pb}(\mathrm{II})$ was obtained when $r=30 \mathrm{mg} / \mathrm{L}$ and in about $20 \mathrm{~min}$ of contact time.

The equilibrium data are best fitted with Langmuir isotherm model, the results demonstrated a favorable and monolayer adsorption mechanism of $\mathrm{Pb}$ (II) onto the selected sawdust.
Open Access This article is distributed under the terms of the Creative Commons Attribution License which permits any use, distribution, and reproduction in any medium, provided the original author(s) and the source are credited.

\section{References}

Ajmal M, Khan AH, Ahmad S et al (1998) Rôle of sawdust in the removal of copper(II) from industrial wastes. Water Res 32:3085-3091

Argun ME, Dursun S, Ozdemir C et al (2007) Heavy metal adsorption by modified oak sawdust:Thermodynamics and kinetics. J Hazard Mater 141:77-85

Bouchemal F, Achour S (2007) Essais d'adsorption de la tyrosine sur charbon actif en grains et en poudre. Larhyss J 6:81-89

Boussahel R, Ouldramoul SA, Harik D et al (2009) Valorisation de la sciure de bois par modification chimique dans l'élimination du pesticide 4,4-DDT présent dans l'eau. Eur J Water Q 40:75-93

Bulut Y, Tez Z (2007) Removal of heavy metals from aqueous solution by sawdust adsorption. J Environ Sci 19:160-166

Cheng G, Varanasi P, Li C et al (2011) Transition of cellulose crystalline structure and surface morphology of biomass as a function of ionic liquid pretreatment and its relation to enzymatic hydrolysis. Biomacromolecules 12(4):933-941

Chitour CE (2004) Physico-chimie des surfaces, les interfaces gazsolide et liquide-solide, vol 2. Office des Publications Universitaire, Algeria

Crist RH, Martin RJ, Crist DR (1999) Interaction of metal ions with acid sites of biosorbents peat moss and vaucheria and model substances alginic and humic acids. Environ Sci Technol 33:2252-2256

Elbariji S, Elamine M, Eljazouli $\mathrm{H}$ et al (2006) Traitement et valorisation des sous-produits du bois. Application à l'élimination des colorants industriels. Comptes Rendus Chimie 9:1314-1321

Fiset J-F, Blais J-F, Ben cheick R, Dayal Tyagi R (2001) Revue sur l'enlèvement des métaux des effluents par adsorption sur la sciure et les écorces de bois. Rev Sci Eau 13(3):323-347

Fujiwara K, Ramesh A, Maki T et al (2007) Adsorption of platinum (IV), palladium (II) and gold (III) from aqueous solutions onto Llysine modified crosslinked chitosan resin. J Hazard Mater 146:39-50

Gad HMH, Omar HA, Khalil MH et al (2013) Factors affecting sorption of $\mathrm{Pb}$ (II) from aqueous solutions using sawdust based activated carbon. J Am Sci 9(10):95-106

Giles CH, MacEwan TH, Nakhwa SN et al (1960) Studies in adsorption. Part XI. A system of classification of solution adsorption isotherms, and its use in diagnosis of adsorption mechanisms and in measurement of specific surface areas of solids. J Chem Soc Lond. 3973-3993. doi:10.1039/JR9600003973

Gong R, Du Y, Li C et al (2011) Thioglycolic acid esterified into rice straw for removing lead from aqueous solution. Iran $\mathrm{J}$ Environ Health Sci Eng 8(3):219

Guimarães D, Carvalho ML, Geraldes V et al (2012) Study of lead accumulation in bones of Wistar rats by X-ray fluorescence analysis: aging effect. Metallomics 4:66-71

Gupta V, Gupta M, Sharma S (2001) Process development for the removal of Lead and chromium from aqueous solutions using Red mud- an aluminium industry waste. Water Res 35:1125-1134

Haider S, Park SY (2009) Preparation of the electrospun chitosan nanofibers and their applications to the adsorption of $\mathrm{Cu}(\mathrm{II})$ and $\mathrm{Pb}(\mathrm{II})$ ions from an aqueous solution. J Membr Sci 328:90-96 
Hall KR, Eagleton LC, Acrivos A et al (1966) Pore and solid diffusion kinetics in fixed bed adsorption under constant pattern conditions. Ind Eng Chem Fundam 5:212-219

Hamane D, Bendjama Z (2007) Utilization of eucalyptus sawdust as an adsorbent for removal of lead from aqueous solution. In: Proceedings of the 10th international conference on environmental science and technology. Kos island, Greece, 5-7 Sept 2007

Hengpeng Y, Zhijuan Y (2010) Adsorption of $\mathrm{Pb}(\mathrm{II})$ onto Modified Rice Bran. Nat Resour 1(2):104-109. doi:10.4236/nr.2010. 12011

Hidalgo-VÁzquez AR, Alfaro-cuevas-villanueva R, Márquez-benavides $L$ et al (2011) Cadmium and lead removal from aqueous solutions using pine sawdust as biosorbent. J Appl Sci Environ Sanit 6(4):447-462

Jianga Y, Pang H, Liao B (2009) Removal of copper(II) ions from aqueous solution by modified bagasse. J Hazard Mater 164:1-9

Kaikake K, Hoaki K, Sunada H et al (2007) Removal characteristics of metal ions using degreased coffee beans: Adsorption equilibrium of cadmium(II). Bioresour Technol 98:2787-2791

Karnitz O Jr, Vinicius Alves Gurgel L, de Perin Melo JC et al (2007) Adsorption of heavy metal ion from aqueous single metal solution by chemically modified sugarcane bagasse. Bioresour Technol 98:1291-1297

Khattria SD, Singh MK (2009) Removal of malachite green from dye wastewater using neem sawdust by adsorption. J Hazard Mater 167:1089-1094

Kim JS, Itoh K, Murabayashi M et al (1999) Pretreatment of the photocatalyst and the photocatalytic degradation of trichloroethylene in the gas-phase. Chemosphere 38:2969-2978

LiewAbdullah AG, Mohd Salleh MA, Siti Mazlina MK et al (2005) Azo dye removal by adsorption using waste biomass: sugarcane bagasse. Int J Eng Technol 2(1):8-13

Marin J, Ayele J (2002) Removal of some heavy metal cations from aqueous solutions by spruce sawdust. I. Study of the binding mechanism through batch experiments. Environ Technol 23:1157-1171

Me Convey IF, Me Kay G (1985) Mass transfer model for the adsorption of basic dyes on woodmeal in agitated batch adsorbers. Chem Eng Process 19:267-275

Mohammadi T, Moheb A, Sadrzadeh M et al (2005) Modeling of metal ion removal from wastewater by electrodialysis. Sep Purif Technol 41:73-82

Naseem R, Tahir SS (2001) Removal of $\mathrm{Pb}$ (II) from aqueous/acidic solutions by using bentonite as an adsorbent. Water Res 35(16):3982-3986

Nasir MH, Nadeem R, Akhtar K et al (2007) Efficacy of modified distillation sludge of rose (Rosa centifolia) petals for lead(II) and zinc(II) removal from aqueous solutions. J Hazard Mater 147:1006-1014

Ofojama AE, Ho Y-S (2008) Effect of temperatures and pH on methyl violet biosorption by Mansonia wood sawdust. Bioresour Technol 99:5411-5417

Ozaki H, Sharma K, Saktaywin W (2002) Performance of an ultralow-pressure reverse osmosis membrane (ULPROM) for separating heavy metal: effects of interference parameters. Desalination 144:287-294

Parka S-I, Kwakb IS, Wonc SW et al (2013) Glutaraldehydecrosslinked chitosan beads for sorptive separation of $\mathrm{Au}(\mathrm{III})$ and $\mathrm{Pd}(\mathrm{II})$ : Opening a way to design reduction-coupled selectivitytunable sorbents for separation of precious metals. J Hazard Mater 248-249C:211-218

Polat H, Erdogan D (2007) Heavy metal removal from waste waters by ion flotation. J Hazard Mater 148:267-273

Ramesh A, Hasegawa H, Sugimoto W et al (2008) Adsorption of gold(III), platinum(IV) and palladium(II) onto glycine modified crosslinked chitosan resin. Bioresour Technol 99:3801-3809

Ren Y, Abbood HA, He F, Peng H, Huang K (2013) Magnetic EDTAmodified chitosan/SiO2/Fe3O4adsorbent: Preparation, characterization, and application in heavy metal adsorption. Chem Eng 226:300-311

Romero-Gonzalez ME, Williams CJ, Gardiner PHE (2001) Study of the mechanisms of cadmium biosorption by dealginated seaweed waste. Environ Sci Technol 35:3025-3030

Rosen JF (1983) The metabolism of lead in isolated bone cell populations: interactions between lead and calcium. Toxicol Appl Pharmacol 71:101-112

Rosin A (2009) The long-term consequences of exposure to lead. Isr Med Assoc J 11:689-694

Samarghandi MR, Azizian S, Shirzad Siboni M et al (2011) Removal of divalent nickel from aqueous solutions by adsorption onto modified holly sawdust: equilibrium and kinetics. Iran J Environ Health Sci Eng 8(2):181-188

Shukla A, Zhang YH, Dubey P et al (2002) The role of sawdust in the removal of unwanted materials from water. J Hazard Mater B95:137-152

Singh J, Mishra NS, Uma, Banerjee S, Sharma YC (2011) Comparative study of physical characteristics of raw and modified sawdust for their use as adsorbents for removal of acid dye. Bioresources 6(3):2732-2743

Taty-Costodes VC, Fauduet H, Porte C, Delacroix A (2003) Removal of $\mathrm{Cd}$ (II) and $\mathrm{Pb}$ (II) ions from aqueous solutions by adsorption onto sawdust of pinus sylvestris. J Hazard Mater 105:121-142

Vaishya RC, Prasad SC (1991) Adsorption of copper (II) on sawdust. Indian J Environ Prot 11:284-289

Xiong C, Pi L, Chen X, Yang L, Ma C, Zheng X (2013) Adsorption behavior of $\mathrm{Hg}^{2+}$ in aqueous solutions on a novel chelating cross-linked chitosan microsphere. Carbohydr Polym 98:1222-1228

Youcef L., Achour S. (2006) Elimination du cuivre par des procédés de précipitation chimique et d'adsorption. Courrier du SavoirNo 07 , pp 59-65

Zongo I, Merzouk B, Palm K et al (2012) Study of an electrocoagulation (EC) unit for the treatment of industrial effluent of Ouagadougou, Burkina Faso. Adv Appl Sci Res 3:572-582

Zou W, Bai H, Gao S, Li K (2013) Characterization of modified sawdust, kinetic and equilibrium study about methylene blue adsorption in batch mode. Korean J Chem Eng 30(1):111-122 